\title{
Sympathetic Neurons in Neonatal Rats Require Endogenous Neurotrophin-3 for Survival
}

\author{
Xin-Fu Zhou and Robert A. Rush \\ Department of Physiology and Centre for Neuroscience, Flinders University of South Australia, Adelaide 5001, \\ Australia
}

\begin{abstract}
Gene deletion of neurotrophin-3 (NT3) results in severe sensory and sympathetic deficits that are incompatible with postnatal life in mice. We have now addressed the question of whether NT3 plays a role in the postnatal animal. An antiserum specific for NT3 and capable of blocking the survival effect of the factor in vitro has been generated and given to neonatal rats. Antiserum administration during either or both of the first 2 postnatal weeks resulted in a 54-74\% reduction in the size of the superior cervical ganglia, reflecting a loss of as many as $\mathbf{8 0} \%$ of all neurons, with a predominant effect on the neuropeptide $Y$ containing subpopulation. The immunoreactivities of NPY, tyrosine hydroxylase, and p75 low affinity NGF receptor in nerve terminals within the mesenteric artery were also reduced, whereas that of the sensory neuron neuropeptide, calcitonin gene related peptide was less affected. These results demonstrate that the majority of sympathetic neurons of the neonatal rat are dependent on endogenous NT3 for their survival at a time when they are also dependent on another survival factor, NGF, thus apparently providing a clear example of a population of neurons requiring for their survival the simultaneous supply of more than one trophic factor.
\end{abstract}

[Key words: sympathetic neurons, development, cell death, neurotrophic factors, neurotrophin-3, rat]

The neurotrophins are a family of target-derived neurotrophic factors consisting of four structurally related proteins including NGF, brain-derived neurotrophic factor (BDNF, Barde et al., 1982; Leibrock et al., 1989), neurotrophin-3 (NT3; Ernfors et al., 1990; Hohn ct al., 1990; Maisonpierre et al., 1990; Rosenthal et al., 1990), NT4/5 (Berkemeier et al., 1991; Hallböök et al., 1991; Ip et al., 1992), and NT6 (Götz et al., 1994). They each support the survival of distinct, but overlapping neuronal populations in vitro. Depriving animals of neurotrophins or their receptors either by administration of specific antibodies or gene deletion results in a variety of neuropathies (Johnson et al., 1980; Ruit et al., 1991, 1992; Klein et al., 1993, 1994; Crowley et al.,

Received Feb. 3, 1995; revised May 15, 1995; accepted June 5, 1995.

We thank Ron Lindsay of Regeneron for rhBDNF, rhNT3, and rhNT4 used for the production and characterization of NT3 antiserum, Eugene Johnson for lgG 192, Bill Blessing and John Oliver for NPY antiserum, Ian Hendry for comments on the manuscript, and Jim Vahaviolos for technical assistance. The work was supported by a grant from NH\&MRC to R.A.R. and by ARC Postdoctoral Fellowship to X.F.Z.

Correspondence should be addressed to Xin-Fu Zhou, Department of Physiology and Centre for Neuroscience, Flinders University of South Australia, G.P.O. Box 2100, Adelaide 5001, Australia.

Copyright (C) 1995 Society for Neuroscience $0270-6474 / 95 / 156521-10 \$ 05.00 / 0$
1994; Ernfors et al., 1994a,b; Farinas et al., 1994; Smeyne et al., 1994). In a recent study, antibody to NT3 has been given to developing chickens, demonstrating a role for NT3 in survival and maturation of sensory neurons as well as glia (Barres et al., 1994; Gaese et al., 1994).

Neurotrophins bind to both low and high affinity receptors on target cells to elicit a cascade of intracellular responses to produce their biological effects (for review, scc Chao, 1992; Raffioni et al., 1993). The low affinity neurotrophin receptor (p75NGFR) is a $75 \mathrm{kDa}$ glycoprotein that binds all four neurotrophins with similar characteristics and is highly expressed in both neuronal and non-neuronal tissue during development and in the adult (Chao et al., 1986; Yan et al., 1988, 1989). Three high affinity neurotrophin receptors named trkA, trkB, and trkC have been identified in the last few years (Martin-Zanca et al., 1989; Klein et al., 1991a; Lamballle et al., 1991; for review, see Barbacid, 1993) and are expressed in both the PNS and CNS (Klein et al., 1990; Martin-Zanca et al., 1990; Tessarollo et al., 1993; 7hou et al., 1993h; Lamballe et al., 1994). In general, it is agreed that trkA functions as a high affinity receptor for NGF (Kaplan et al., 1991; Klein et al., 1991b), trkB for BDNF and NT4 (Klein et al., 1991b, 1992; Soppet et al., 1991; Squinto et al., 1991), and trkC for NT3 (Lamballe et al., 1991). This specificity is not absolute as some cross-talk is apparent (Ip et al., 1993; for review, see Barbacid 1993).

The genesis, development and ccll death phases of sympathetic neurons have been well described (De Champlain et al., 1970; Aanaya et al., 1973, 1976; Hendry, 1977; Wright et al., 1983, Rubin, 1985a-c). Sympathetic precursor cells in the rat first appear on E11 in the thoracic region or on E12 in the cervical region. These cells proliferate, migrate and aggregate forming ganglia along the sympathetic chain between E12 and E14 (Rubin, 1985c). Differentiation begins on E12 and the first axons emerge a few days later. Maturation continues with the synthesis of catecholamines, preganglionic inputs and dendrite formation (Rubin, 1985a-c). The number of differentiated neurons reaches a peak hy hirth. Postnatally, a proportion of neurons die after their axons arrive into peripheral innervation fields. Approximately one-third of all neurons in the superior cervical ganglion (SCG) die during the first week after birth when these neurons critically rely on NGF for their survival (Wright et al., 1983). This naturally occurring sympathetic neuron death can be prevented by exogeneous NGF (Hendry and Campbell, 1976) or exaggcrated by deplction of endogenous NGF with antibodies (Levi-Montalcini and Booker, 1960; Hendry and Campbell, 1976; Goedert et al., 1978).

These experiments, demonstrating the physiological role of 
NGF in sympathetic neurons, have established the fundamental theory of neurotrophism. However, indirect evidence has shown that subpoulations of sympathetic neurons are also dependent on factors other than NGF. For example, during late development sympathetic neurons express both trkA and trkC (Dixon et al., 1994), suggesting both NGF and NT3 are required. NT3 is known to bind specifically to sympathetic neurons (Dechant et al., 1993) and to support the survival of sympathetic neurons of the chick embryo and mouse neonate in vitro (Maisonpeirre et al., 1990; Rosenthal et al., 1990; Lee et al., 1994). NT3 is also shown to increase the number of mature sympathetic neurons by promoting the survival of proliferating sympathoblasts (Birren et al., 1993; DiCicco-Bloom et al., 1993). Furthermore, consistent with these in vitro studies, deletion of the NT3 gene results in severe sympathectomy in neonatal mice (Ernfors et al., 1994b; Farinas et al., 1994). However, the question of whether NT3 acts as a survival factor postnatally in the intact animal has not been addressed. To answer this question, we have raised polyclonal NT3 antibodies in rabbits which specifically block the biological activity of NT3 both in vitro and in vivo. The NT3 neurotrophic action has been dissociated from its mitogenic or proliferative action by administration of the antiserum to neonatal rats. Our study shows that NT3 is a survival factor for postnatal sympathetic neurons at a time when they are also dependent on NGF.

\section{Materials and Methods}

\section{NT3 antiserum}

The antiserum was raised against rhNT3 in a rabbit according to a method developed for small molecules (Pow and Crook, 1993). Briefly, $50 \mu \mathrm{g}$ of rhNT3 was conjugated to porcine thyroglobulin with glutaradehyde and injected into a rabbit as described previously (Zhou et al., 1993a). The antiserum used for this study was collected after 12 injections.

\section{Dot blot}

Different amounts of mouse NGF, rhBDNF, and rhNT3 in $1 \mu$ l of PBS were dotted on nitrocellulose paper as shown in Figure 1.1. After blocking in $20 \%$ normal horse serum (NHS), the membrane was incubated overnight in the NT3 antiserum at a dilution of 1 in 2000 in PBS containing $1 \% \mathrm{NHS}$ and $0.3 \%$ Triton X-100. The membrane was rinsed, washed three times (15 min each) in PBS containing 1\% Tween-20 (PBST), and incubated in biotinylated antibodies to rabbit IgG (1:500 dilution; Vector Lab) in PBS containing $1 \%$ NHS for $2 \mathrm{hr}$ at room temperature. After several washes the membrane was incubated in $\mathrm{ABC}$ complex (1:100 dilution; Vector Lab) for $1 \mathrm{hr}$ at room temperature. After rinsing in Tris buffered saline (TBS) the membrane was developed in TBS containing $0.05 \%$ diaminobenzidine (DAB), $0.3 \%$ nickel sulfate and $0.002 \% \mathrm{H}_{2} \mathrm{O}_{2}$ for $10 \mathrm{~min}$ at room temperature.

\section{Bioassay}

Fertile White Leghorn eggs were incubated at $38^{\circ} \mathrm{C}$ in a moisturized incubator. Chick dorsal root ganglia (DRG) were dissected at E8 and cultured in RPMI 1640 culture medium from CSL supplemented with $10 \%$ fetal calf serum containing $10 \mathrm{ng} / \mathrm{ml}$ of mouse NGF, rhBDNF, or rhNT3 in the presence or absence of antiserum to rhNT3 at the dilutions shown in Figure 1.2. After $24 \mathrm{hr}$ culture, the neurite outgrowth from each ganglion was scored according to Ebendal et al. (1980). Each point represents an average of 3-5 DRG results.

\section{Treatment of neonates with NT3 antiserum}

Three experiments were performed with two groups of rats in each experiment. Experiment 1: Rats were injected subcutaneously (s.c.) with either NT3 antiserum or normal rabbit serum (NRS; $n=5$ for each group) on postnatal days (P) 1 (10 $\mu \mathrm{l} / \mathrm{gm}$ body weight; b.w.), 3, 5, and $7(5 \mu \mathrm{l} / \mathrm{gm}$ b.w. for other time points). Treated and control rats were killed at $\mathrm{P} 8$ by anaesthetic overdose and perfused with $0.1 \mathrm{M}$ phosphate buffer followed by Zamboni's fixative. Experiment 2: Rats were injected
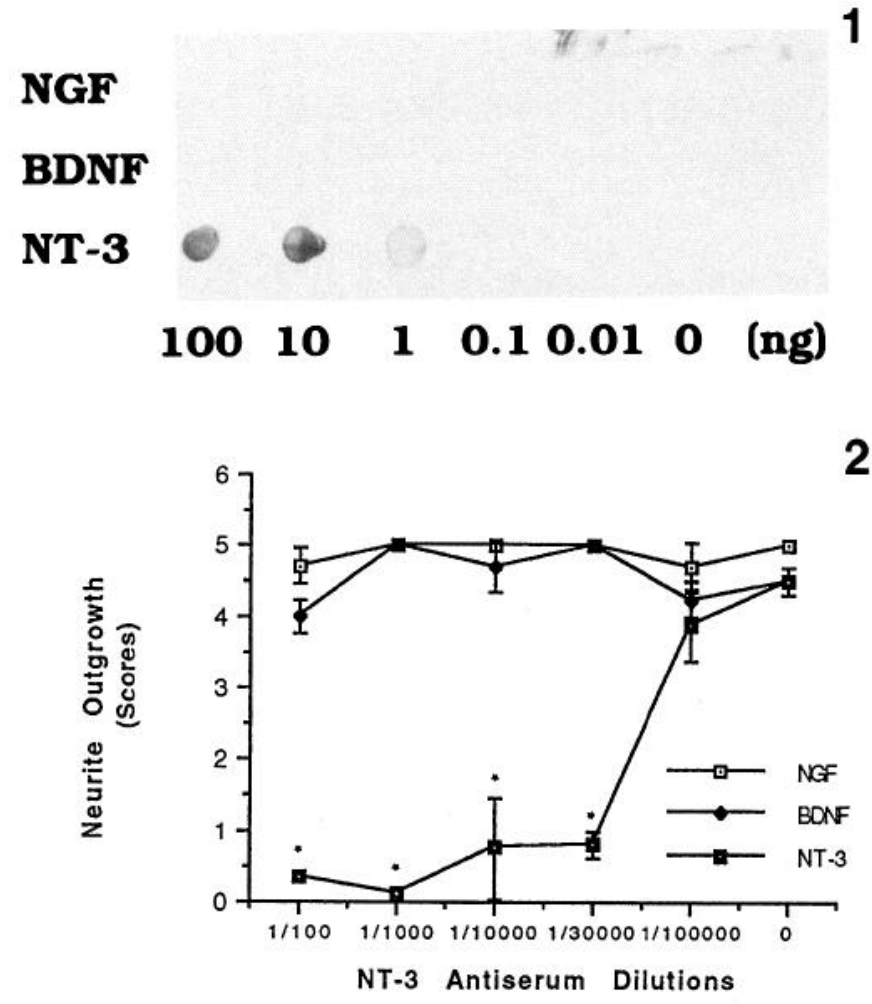

Figure 1. Characterization of NT3 antiserum by immunoblot and bioassays. 1, Dot blot analysis showing the crossreactivities of NT3 antiserum to neurotrophins. The antiserum recognized rhNT3 at $0.1 \mathrm{ng}$ but not 100 ng NGF or 10 ng BDNF. 2, Effects of antiserum to rhNT3 on the neurite outgrowth of DRG promoted by different neurotrophins in culture. NT3 antiserum diluted from 1 in 100 to 30,000 significantly inhibited neurite outgrowth but was without effect on NGF and BDNF induced growth. Each point represents an average of results from 3-5 DRG.

s.c. with either the NT3 antiserum or NRS ( $n=4$ for each group) every second day from P1 (10 $\mu \mathrm{g} / \mathrm{gm}$ b.w.) to P13 (5 $\mu \mathrm{l} / \mathrm{gm}$ b.w. for other time points). The rats were killed at P14 as described above. Experiment 3: Rats were injected s.c. with either NT3 antiserum or NRS $(n=4$ for each group) at P7 (10 $\mu \mathrm{l} / \mathrm{gm}$ b.w.), P9, P11, and P13 (5 $\mu \mathrm{l} / \mathrm{gm}$ b.w. for other time points) and killed at P14 as described above. SCG, stellate ganglia (SG), superior mesenteric ganglia (SMG), $\mathrm{L}_{5}$ DRG and trigeminal ganglia were dissected and ganglia weighed and photographed after removal of moisture and surrounding tissues.

\section{Histology}

SCG were dehydrated in graded alcohols and xylene, embedded in paraffin and sectioned at $10 \mu \mathrm{m}$. Sections were dewaxed in xylene, rehydrated in graded alcohol and water, stained with $1 \%$ thionin and observed under a light microscope. Neurons with visible nuclei and wellstained cytoplasm were counted with a $20 \times$ objective on every fifth section. The diameters of more than 100 nuclei in the largest section were measured with a $40 \times$ objective. The total number of neurons was calculated and corrected with Abercrombie's equation (Abercrombie et al., 1946). The significant differences between control and experimental groups were tested with an unpaired Student's $t$ test.

\section{Measurement of soma area of sympathetic neurons}

Several sections of NRS- and NT3 antiserum-treated SCG from experiment 2 were used for the measurement of soma size of sympathetic neurons. Two diameters at right angles were measured at $400 \times$ magnification in each neuron having a clear nucleus. Soma areas were calculated with the formula $d I \times d 2 \times \pi / 4$ described previously (Zhou et al., $1994 \mathrm{~b}$ ), where $d 1$ and $d 2$ represent the two diameters. The size distribution of soma areas from each treatment was plotted as a percentage of the total numbers of neurons measured. 


\section{Immunohistochemistry}

$N G F$ in SCG. Sprague-Dawley rats, 6 weeks of age, were injected intraperitoneally (i.p.) with either $1.5 \mathrm{ml}$ of NRS, NGF antiserum or NT3 antiserum; $72 \mathrm{hr}$ after injection, the rats were briefly perfused with $50 \mathrm{ml}$ of acetate buffer, $\mathrm{pH} 3.0$ (5\% acetic acid), followed by $500 \mathrm{ml}$ of Zamboni's fixative as previously described (Zhou et al., 1994a). SCG were dissected, postfixed in Zamboni's fixative for $2 \mathrm{hr}$, cryoprotected in $30 \%$ sucrose for $1 \mathrm{hr}$ and sectioned at $30 \mu \mathrm{m}$ with a cryostat microtome. The free floating sections were washed three times (15 min each) in $50 \%$ ethanol and once in PBS, blocked in $20 \%$ NHS and incubated overnight in affnity purified NGF antibodies $(1 \mu \mathrm{g} / \mathrm{ml})$ raised in sheep. The sheep NGF antibodies have been characterized previously by immunoblot (Zhou et al., 1994a) and ELISA (Zettler et al., unpublished observations), showing that they recognize NGF but not BDNF or NT3. After washing in PBST, the sections were incubated in biotinylated secondary antibodies against sheep IgG (1:500 dilution; Vector Lab) for 2 $\mathrm{hr}$ and followed by $\mathrm{ABC}$ kit (1:200 dilution) for $1 \mathrm{hr}$ with washes between incubations. The sections were developed in DAB solution with nickel intensification. The sections were dehydrated in graded alcohols and xylene and mounted in xylene based medium for observation and photography.

NPY, p75NGFR, TH, and CGRP in SCG and mesenteric arteries. Paraffin embedded SCG were sectioned at $10 \mu \mathrm{m}$ and processed for immunohistochemistry for NPY, and p75NGFR and TH. Mesenteric arteries were dissected free from connective tissues and veins. Whole tissues were pinned on a petri dish and processed for NPY, TH, p75NGFR, and CGRP. NPY antiserum raised in sheep was diluted at 1:2000 (for SCG) or 1:5000 (mesenteric arteries), mouse monoclonal antibody to TH (INCSTAR, lot\# 22941) was diluted at 1:1000, mouse monoclonal LNGFR antibody (IgG192) was diluted at 1:500 and CGRP antibodies raised in goat was diluted at 1:5000. Sections and mesenteric arteries from control and experimental groups were mounted on the same slides or treated in the same petri dish, and processed and developed for the same length of time to reduce variability. After development, mesenteric arteries were mounted on gelatin-coated slides, coverslipped, observed, and photographed.

\section{Results}

\section{Characteristics of the NT3 antiserum}

Dot blot analysis (Fig. 1.1) showed that the NT3 antiserum has no crossreactivity with NGF even at an amount of $100 \mathrm{ng}$ but slight $(0.1 \%)$ cross-reactivity with rhBDNF. The antiserum could detect as little as $0.1 \mathrm{ng}$ of rhNT3. Bioassays (Fig. 1.2) showed that mouse (m) NGF, rhBDNF, and rhNT3 all promoted DRG explant outgrowth and that NT3 antiserum at dilutions of 1:100 to $1: 30,000$ could inhibit only the growth induced by NT3. These results indicate that the antiserum used in this study is specific for NT3 with little or no crossreactivities with BDNF or NGF. This conclusion is further supported by additional experiments. Immunoassays showed that the NT3 antiserum crossreacted with $\mathrm{mNGF}$ at a level of approximately $0.2 \%$ (data not shown). Furthermore, our "in vivo adsorption" technique (Zhou et al., 1994a) was used to show that NT3 antiserum did not deplete the endogenous NGF immunoreactivity accummulated in sympathetic neurons of SCG. Since in neonatal animals the administration of both NGF and NT3 antisera results in the death of sympathetic neurons, this experiment was performed in older rats. Figure 2 shows that, in 6 week old rats, NGF-ir is readily detectable in most sympathetic neurons after injection of NRS three days earlier (Fig. 2.1), but not in neurons from animals treated with NGF antiserum (Fig. 2.2). In contrast, injection of NT3 antiserum had little effect on NGF-ir (Fig. 2.3), indicating the inability of this antiserum to block the uptake and transport of endogenous NGF by sympathetic neurons.

\section{Effects of NT3 antiserum on sensory and motor neurons}

No significant differences were seen in animal sizes between NRS and NT3 antiserum treated pups. The feeding behaviour
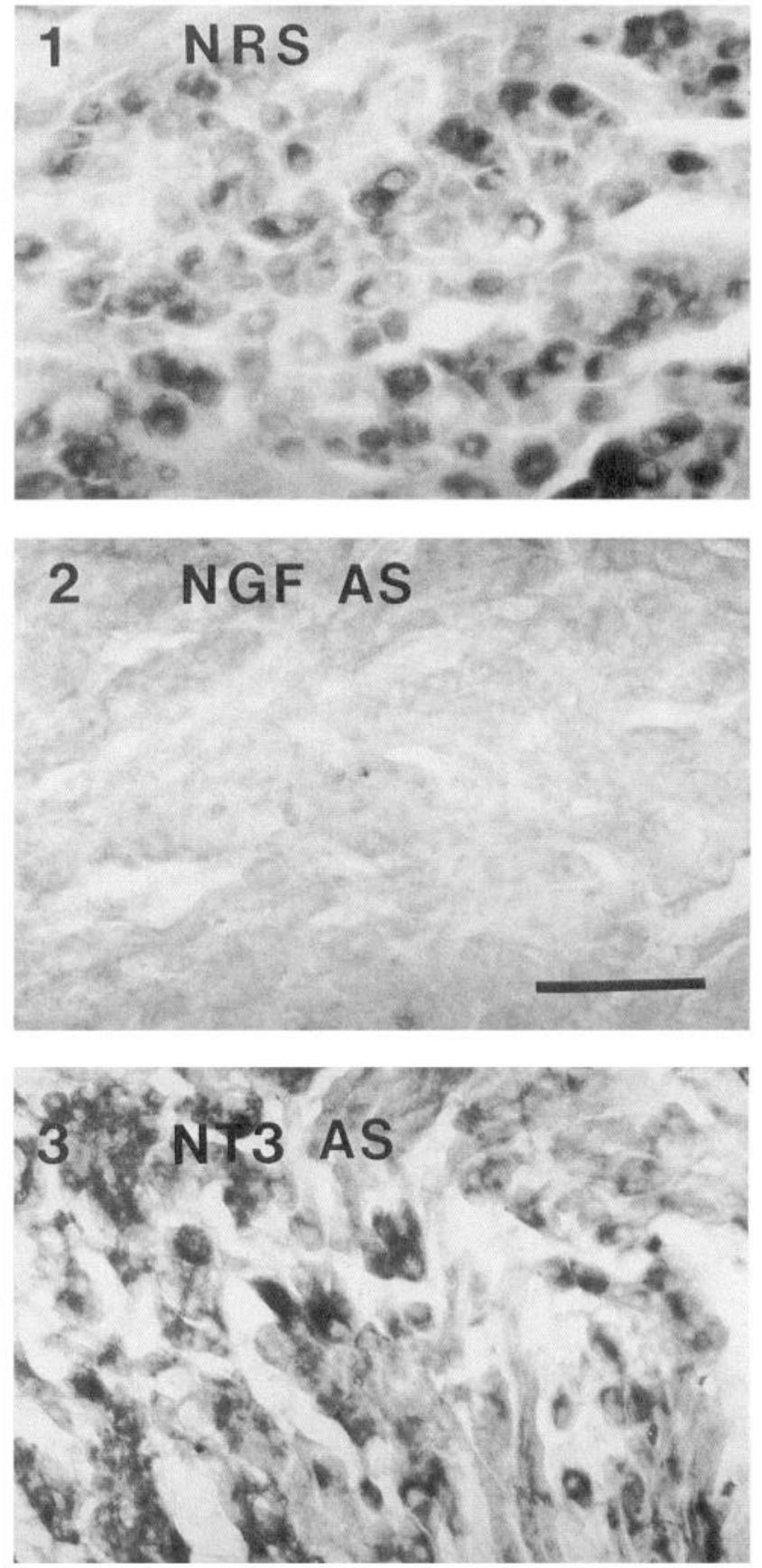

Figure 2. Localization of NGF-like immunoreactivity in sympathetic neurons of SCG with NGF immunohistochemistry in 6 week old rats. 1, Normal rabbit serum treated SCG showing NGF-ir in sympathetic neurons. 2, NGF-ir in sympathetic neurons was absent in animals treated with NGF antiserum. 3, NGF-ir in sympathetic neurons was not significantly changed in animals receiving NT3 antiserum. Scale bar, $100 \mu \mathrm{m}$.

and movement development of antiserum treated rats were also normal. The weights of $\mathrm{L}_{5}$ DRG $(0.85 \pm 0.05)$ and trigeminal ganglia $(5.42 \pm 0.26 \mathrm{mg})$ in antiserum treated pups were slightly, but significantly, reduced compared with controls (DRG: 1.15 $\pm 0.04 \mathrm{mg}, P<0.01$; trigeminal ganglia: $6.62 \pm 0.27 \mathrm{mg}, P$ $<0.01$ ). No obvious morphological changes in sensory neurons of L5 DRG and motor neurons in brain stem and spinal cord were seen after antiserum treatment for 1 or 2 weeks. 


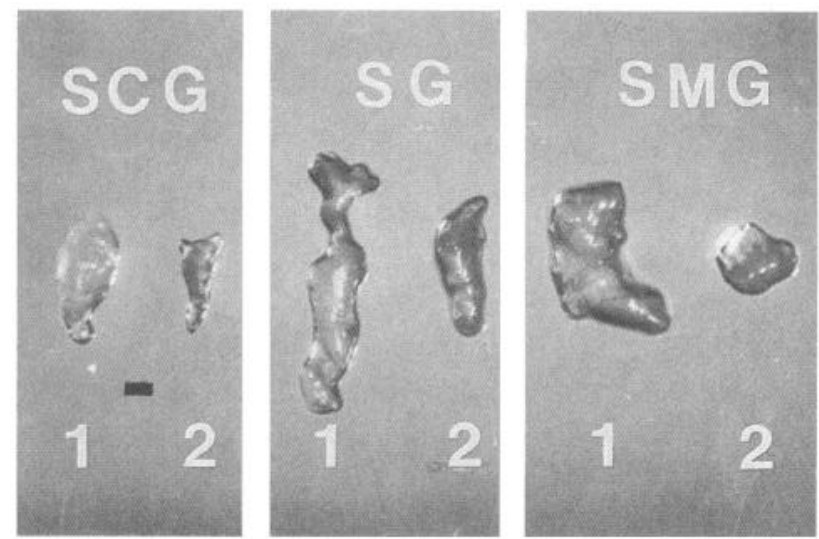

Figure 3. Effect of NT3 antiserum on size of SCG (superior cervical ganglia), $S G$ (stellate ganglia), and $S M G$ (superior mesenteric ganglia). 1 , NRS treated; 2 , NT3 antiserum treated in experiment 2 . Scale bar, $0.5 \mathrm{~mm}$.

\section{Effect of NT3 antiserum on sympathetic neurons}

Injection of NT3 antiserum to neonatal rats in all three experiments significantly reduced the volume of sympathetic ganglia including SCG, SG, and SMG. Administration of the antiserum for two weeks (from P1 to P14, experiment 2) induced the most significant damage, markedly reducing the size of the SCG, SG and SMG (Fig. 3). Quantitative data showed that the weights of the SCG and SG in these rats were reduced by $74.3 \%$ and $73.4 \%$, respectively, in comparison with normal rabbit serum (NRS) controls (Table 1). Interestingly, the use of the antiserum for one week either from P1 to P8 (experiment 1) or from P7 to P14 (experiment 3 ) resulted in a less marked, but still highly significant reduction of SCG weight.

The reduction of SCG size was accompanied by a significant loss of sympathetic neurons (Fig. 4, Table 2). As shown in Figure 4.2, a few, widely dispersed neurons from experiment 2 can be seen scattered across the section surrounded by increased numbers of non-neuronal cells. Pyknotic cells in each section from antiserum treated rats could be easily identified and the number of non-neuronal cells was also increased. The total number of neurons in the SCG of NT3 antiserum-treated rats from experiment 2 was reduced by $80.6 \%$. As shown in Figure 4.3 , neurons in the SCG from rats killed at P8 after NT3 antiserum treatment (exepriment 1 ) were smaller and contained less cytoplasm than controls. Their total number was reduced by $60.4 \%$. In those animals treated with antiserum for the second postnatal week only (experiment 3 ), the density of sympathetic neurons was also significantly reduced (Fig. 4.4) with the total number of neurons decreased by $61.3 \%$.

\section{Effect of NT3 antiserum on the size distribution of soma areas}

In SCG from control in experiment 2, the size distribution of neuronal soma areas ranging from 74 to $460 \mu \mathrm{m}^{2}$ with an average of $2346 \mu \mathrm{m}^{2}$ (Fig. 5). In contrast, the average soma areas of neurons from antiserum-treated rats was $265 \pm 11 \mathrm{~mm}^{2}$ with a much wider distribution range of 33-817 $\mu^{2}$. These differences were highly significant $(p<0.01)$ and indicated a shift away from the mean towards both extremities, suggesting that most sympathetic neurons undergo either atrophy and hypertrophy as a consequence of the antiserum treatment.

\section{Effects of NT3 antiserum on neuronal markers}

Immunohistochemical data showed that the intensity of the tyrosine hydroxylase (TH) immunoreactvity (ir) in the remaining sympathetic neurons of the NT3 antiserum treated rats in experiment 2 was similar to NRS controls (data not shown). Neuropeptide Y (NPY)-ir neurons in P14 control SCG represented $58 \%$ of the total (Fig. 6.1) whereas only $28 \%$ of neurons were NPY-ir in NT3 antiserum treated rats (Fig. 6.2, Table 3). Compared with the NRS controls (Fig. 6.3), the number of NPY-ir nerve terminals innervating mesenteric arteries was also reduced after NT3 antiserum treatment (Fig. 6.4). However, the staining intensity of the surviving NPY-ir terminals was not reduced. Figure 6.5 and Figure 6.7 show the localization of tyrosine hydroxylase $(\mathrm{TH})$-ir and p75NGFR-ir within the nerve terminals in NRS treated rats. Both the intensity and the number of THir as well as p75NGFR-ir nerve teminals of mesenteric arteries were significantly reduced after NT3 antiserum treatment (Fig. 6.6 and 6.8). The number of calcitonin gene-related peptide (CGRP)-ir fibers also appeared to be slightly reduced in this tissue (Fig. 6.9 and 6.10).

\section{Discussion}

\section{Antiserum specificity}

The specificity of the antiserum used in these experiments is critical to the validity of the findings. Therefore, several experiments were performed to demonstrate that the NT3 antiserum used is specific for this neurotrophin only and, in particular, has little or no cross-reactivity with NGF. First, the NT3 antiserum reacted with rhNT3 in the range of $0.1-100 \mathrm{ng} / \mu \mathrm{l}$ but showed no cross-reactivity with mNGF on dot blot analysis even at the highest concentration (Fig. 4.1). Cross-reactivity with rhBDNF was estimated at a maximum of $0.1 \%$. Second, bioassays showed that mNGF, rhBDNF, and rhNT3 all promoted DRG explant outgrowth, but that only NT3-induced growth was inhibited by the NT3 antiserum. This effect was seen at antiserum dilutions ranging from 1:100 to 1:30,000 (Fig. 4.2). Third and most importantly, "in vivo absorption" of NT3 with the specific antiserum in older rats failed to reduce the level of NGF-ir in

Table 1. Effects of NT3 antiserum on wet weight of sympathetic ganglia

\begin{tabular}{lllll} 
& & \multicolumn{2}{l}{ Wet weight $(\mathrm{mg}) \pm$ SEM $(n)$} & \\
\cline { 3 - 4 } Ganglia & Treatment & NRS & NT3 AS & Reduction \\
\hline SCG & exp. 1 (P1-8) & $0.68 \pm 0.07(6)$ & $0.30 \pm 0.04(5)$ & $55.5 \% *$ \\
SCG & exp. 2 (P1-14) & $0.87 \pm 0.07(8)$ & $0.22 \pm 0.04(8)$ & $74.3 \%^{* *}$ \\
SCG & exp. 3 (P7-14) & $0.82 \pm 0.05(8)$ & $0.37 \pm 0.02(6)$ & $55.0 \% * *$ \\
SG & exp. 2 (P1-14) & $1.06 \pm 0.04(6)$ & $0.28 \pm 0.04(6)$ & $73.4 \% * *$ \\
\hline
\end{tabular}

$\overline{\text { SCG, Superior cervical ganglia; SG, stellate ganglia; } n \text { represents the number of ganglion (from both sides). *, } p<}$ $0.01 ;{ }^{* *}, p<0.001$. 

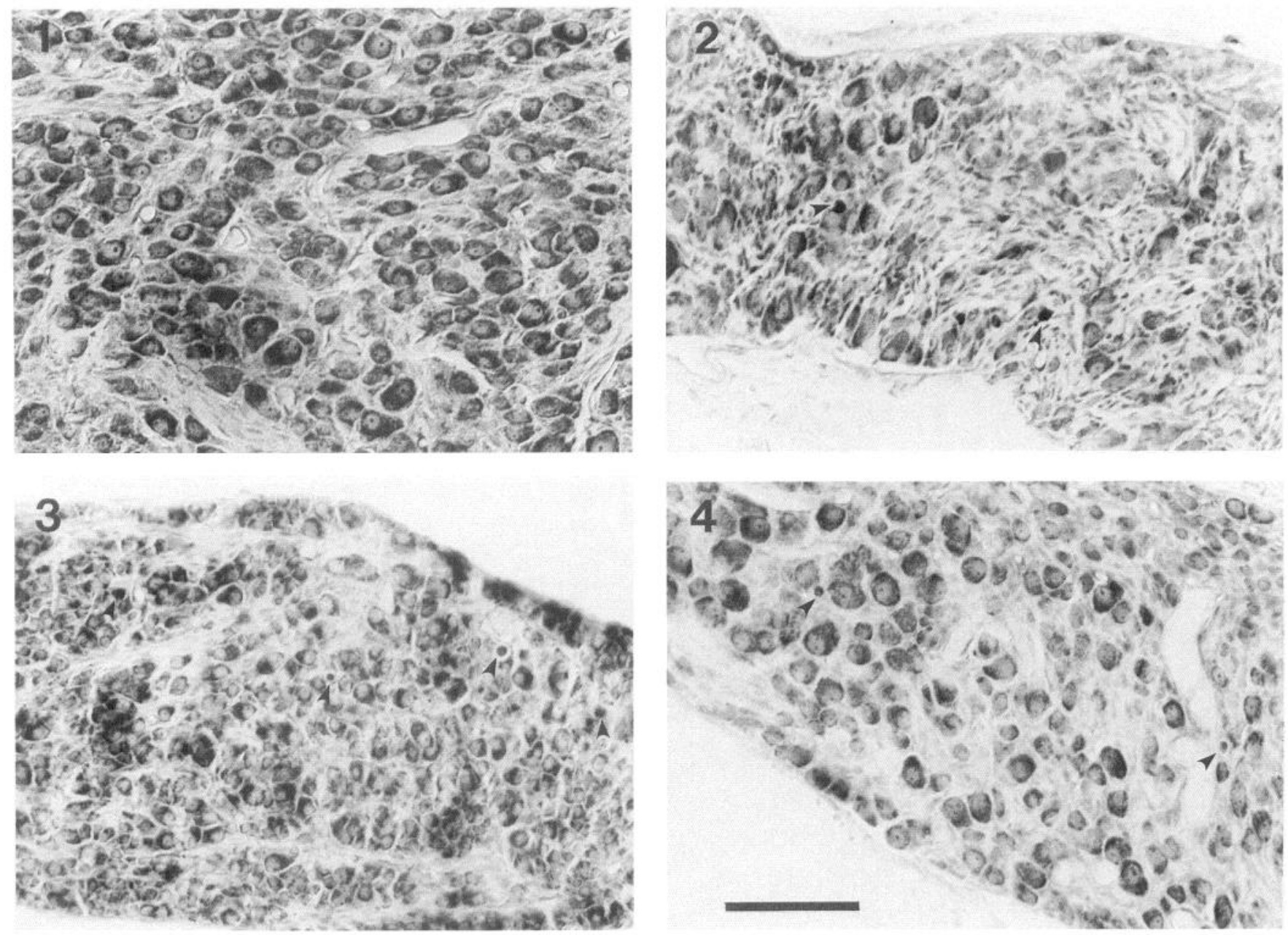

Figure 4. Histological analysis of thionin stained sections from superior cervical ganglia of control and treated rats. 1, Micrograph from a section of the NRS treated rats of experiment $2 ; 2$, section from NT3 antiserum treated rat of experiment $2 ; 3$, section from NT3 antiserum treated rat of experiment $1 ; 4$, section from NT3 antiserum treated rat of experiment 3 . Scale bar, $100 \mu \mathrm{m}$.

sympathetic neurons of SCG. In contrast, NGF-ir is lost from these neurons in rats injected with rabbit antiserum to NGF (Zhou et al., 1994a). These experiments indicate that the NT3 antiserum is unable to significantly block the uptake of endogenous NGF into these neurons. Fourthly, the antiserum fails to detect NGF-ir within the mouse salivary gland under conditions which allow detection with NGF antiserum (data not shown). Finally, the NT3 antiserum shows less than $0.2 \%$ cross-reactivity with NGF in a two site ELISA. These results indicate that the antiserum used in this article is specific to NT3, displaying little or no cross-reactivity with BDNF or NGF, so that the findings are unlikely to be due to an inhibition of endogenous NGF. Al-

Table 2. Effects of NT3 antiserum on the number of sympathetic neurons in SCG

\begin{tabular}{llll} 
& \multicolumn{2}{l}{ Number of neurons \pm SEM $(n)$} & \\
\cline { 2 - 3 } Treatment & NRS & NT3 AS & Reduction \\
\hline Exp. 1 (P1-8) & $21,465 \pm 848$ & $(5) 8468 \pm 1426(5)$ & $60.4 \% * *$ \\
Exp. 2 (P1-14) & $20,464 \pm 625(4) 3984 \pm 1333(4)$ & $80.6 \% * *$ \\
Exp. 3 (P7-14) & $21,545 \pm 1100(4) 8300 \pm 400(4)$ & $61.3 \% * *$ \\
\hline$* *, p<0.001$. & & &
\end{tabular}

though there are reports that some antisera to neurotrophins show limited cross-reactivity with other members of the family (Murphy et al., 1993; Negro et al, 1993), specific antisera have also been described (Ruit et al., 1991, 1992; Zhou et al, 1994a; Zettler et al., unpublished observations).

\section{Effect of NT3 antiserum on neuronal markers}

In the present study, we have found that the NT3 antiserum significantly reduced the immunoreactivities of neuronal markers NPY, TH, p75NGFR, and possibly CGRP in the mesenteric arteries. The extent of the loss of these neuronal markers varied, so that NPY-ir and TH-ir were most affected and CGRP-ir least affected. The reduction of these neuronal markers may simply reflect a reduction of sympathetic innervation within the artery as a result of the neuronal loss in sympathetic ganglia, or alternatively, a downregulation of these markers from a subpopulation of the neurons. Loss of CGRP-ir in the mesenteric arteries may reflect either its loss from sympathetic neurons expressing CGRP-ir (Schmitt et al., 1988; Kummer and Heym, 1991; Majewski and Heym, 1992; Heym et al., 1993) or from sensory neurons or both. That NT3 antiserum preferentially reduced the number of NPY-ir neurons in the SCG may indicate a greater sensitivity either for survival and/or peptide expression. There 


\section{Effect of NT3 Antiserum on Sympathetic Neuron Soma Size Distribution}

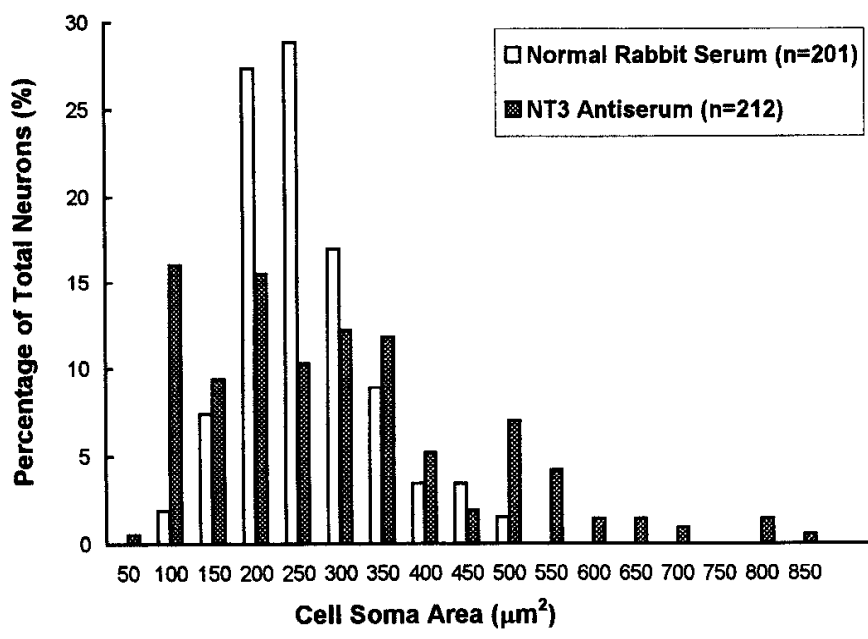

Figure 5. Effects of NT3 antiserum on the size distribution of soma areas of sympathetic neurons in the superior cervical ganglia. The soma sizes were measured and calculated as described in Materials and Methods. The size distribution was plotted as a percentage of total neurons measured.

is indirect evidence showing that NPY-ir in sympathetic neurons is regulated by factors distinct from NGF (Cowen et al., 1993). For example, injury to sensory innervation of tooth pulp induces sprouting of substance P (SP)-ir and CGRP-ir sensory, but not NPY-ir sympathetic fibers (Edwall et al., 1985; Oswald and Byers, 1993). Also, no compensatory sprouting of NPY-ir sympathetic fibers was found after sensory denervation of tooth pulp in cats (Edwall et al., 1985) or rats (Oswald and Byers, 1993). Furthermore, mRNA ${ }^{N P Y}$ expression in the SCG of rat is not altered by NGF treatment (Miller et al., 1991). However within the SMG, NPY-ir neurons appear sensitive to NGF antibodies, although a non-NGF sensitivc population of neurons innervating the enteric plexuses has been demonstrated (Hill et al., 1985).

\section{Effect of NT3 antiserum on the size distribution of soma}

Ilypertrophy of a subpopulation of sympathetic neurons following NGF antibody treatment in neonatal rats is a well-documented phenomenon (Cohen, 1960; Levi-Montalcini and Booker, 1960; Hendry and Campbell, 1976). In the present study we found that NT3 antiserum treatment induced both hypertrophy and atrophy. The reason for the hypertrophy is not clear. Exogenous NGF applied to neonatal animals can induce the hypertrophy of sympathetic neurons (Hendry and Campbell, 1976). It is therefore possible that more NGF in the targets is available for the few surviving sympathetic neurons. The atrophy of sympathetic neurons following the NT3 antiserum treatment may be due to the reduced trophic support resulting from the depletion of endogenous NT3.

\section{NT3 is a survival factor for sympathetic neurons}

The use of gene deletion experiments has provided important new information concerning the physiological roles of the neurotrophins (Crowley et al., 1994; Ernfors et al., 1994a,b; Farinas et al., 1994; Jones et al., 1994). However, the usefulness of the technique is currcntly limited by the inability to time the onset of growth factor depletion; a limitation which we have sought to overcome by production of high titer, specific antisera to each factor. The current study has identified an ability of such an antiserum to kill the majority of sympathetic neurons in neonatal rats, thus indicating that endogenous NT3 acts as a survival factor for these neurons. The results are, of course, reminiscent of experiments performed by Cohen (1960) and Levi-Montalcini and Brook (1960) showing that the administration of NGF antiserum to neonatal animals leads to widespread sympathectomy. That one neuron is dependent in vivo on two separate factors raises the intriguing question of whether both neurotrophins are required for neuronal survival sequentially or in parallel. Since more than $80 \%$ reduction in neuron number is achieved by depletion of either NGF or NT3, there is little indication that each neurotrophin supports a separate neuronal population, with the possible exception of the SMG. While our findings indicate an overlapping dependence on two factors, there is also recent evidence for a sequential action. A switch in survival factor requirement in vitro from NT3 to NGF can be demonstrated during the late embryonic period and is accompanied by a change in synthesis of neurotrophin receptors from trk $C$ to trk $A$ (Schecterson and Bothwell, 1992; Birren et al., 1993; DiCiccoBloom et al., 1993), although trk C expression continues for several weeks postnatally (Dixon et al., 1994). Deletion of either the NGF (Crowley et al., 1994) or NT3 gene (Ernfors et al. 1994b; Farinas et al., 1994b) in embryonic mice results in more than $50 \%$ reduction of sympathetic neurons, but this finding does not rule out a parallel or overlapping action.

Is the sensitivity to NT3 uncovered in the present experiments due to a declining sensitivity of immature neurons or are sympathetic neurons sensitive to the factor throughout the life of the animal? Evidence for the latter possibility is only indirect at present, but nevertheless should be considered. In adult rats, sympathctic ncurons are capable of transporting labeled NT3 (DiStefano et al., 1992) and preliminary evidence indicates that trk C-ir is present within sympathetic nerve terminals of the mesenteric artery (Zhou, Vahaviolos, and Rush, unpublished findings). In situ hybridization studies (Scarisbrick et al., 1993) and biochemical analysis (Zhou, Palm and Rush, unpublished data) have identified the presence of $\mathrm{mRNA}^{\mathrm{NT} 3}$ in the wall of aorta of embryonic animals and in extracts of the mesenteric vasculature from 3 week old rats. Finally, post-mortem analysis indicates that the volume of sympathetic ganglia from one NT3 immunized rabbit (the antiserum from which was used in this study) were reduced in size compared with animals immunized with other molecules. Thus, there is sufficient indirect evidence to suggest that the requirement for NT3 may persist into adult life.

Figure 6. Effects of NT3 antiserum on immunoreactivities of NPY in SCG (panels 1 and 2) and NPY, TH, LNGFR, and CGRP in mesenteric arteries (panels 3-10). Samples from three NT3 antiserum and three NRS treated-rats as described in experiment 2 were processed simultaneously for immunohistochemistry and yielded consistent results. Panels $7,3,5,7$, and 9 are from NRS treated rats and 2, 4, 6, 8, and 10 from NT3 antiserum treated rats. Scale bar, $100 \mu \mathrm{m}$. 

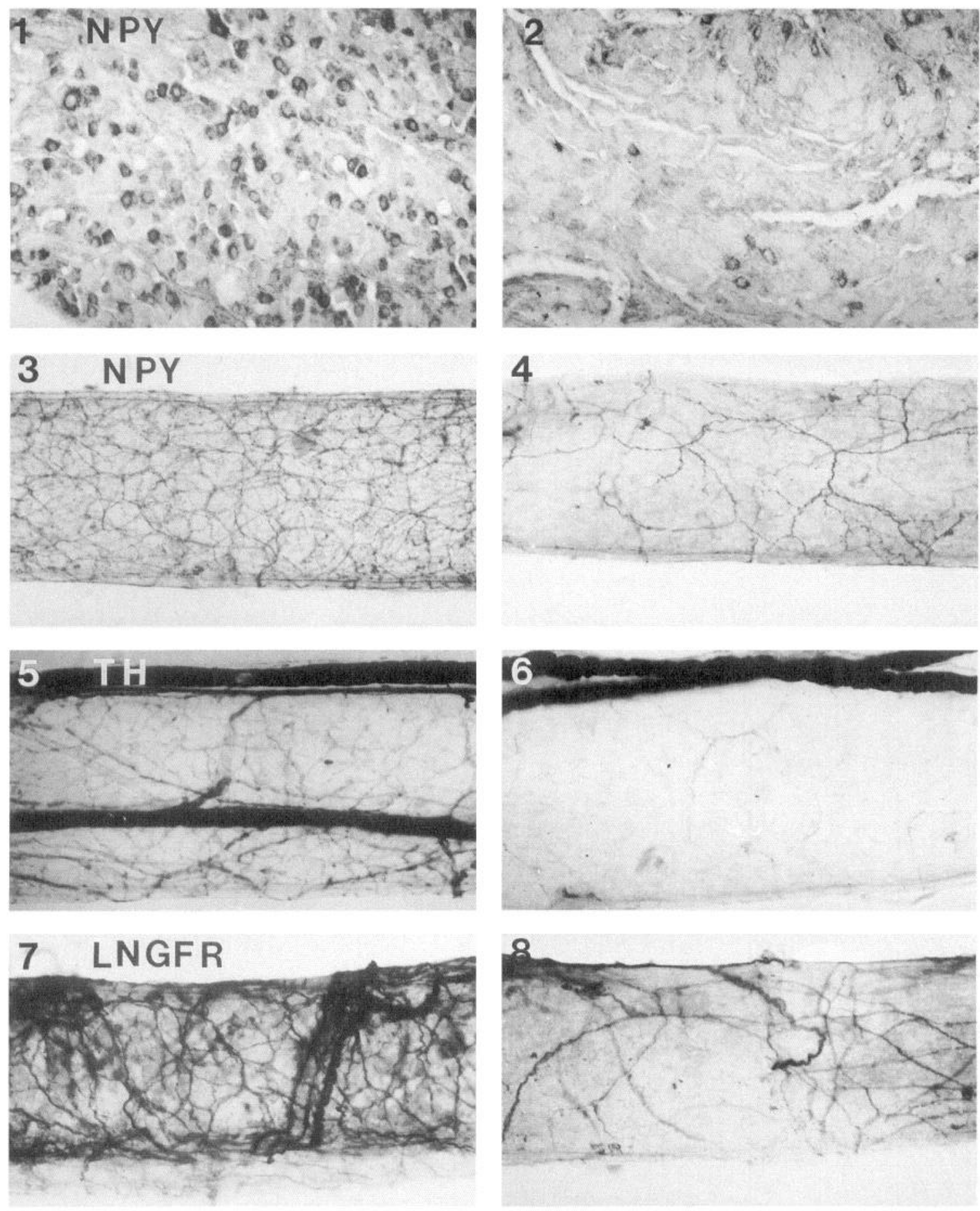

9 CGRP

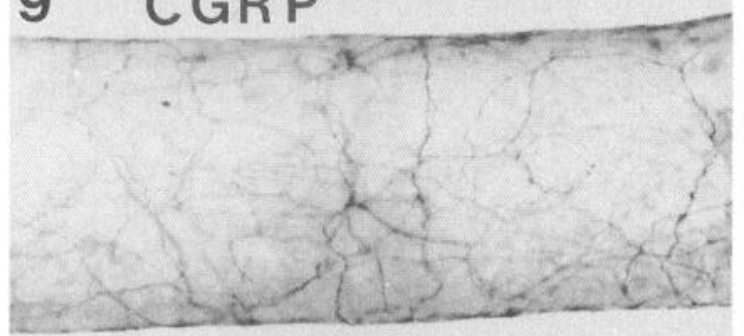

10

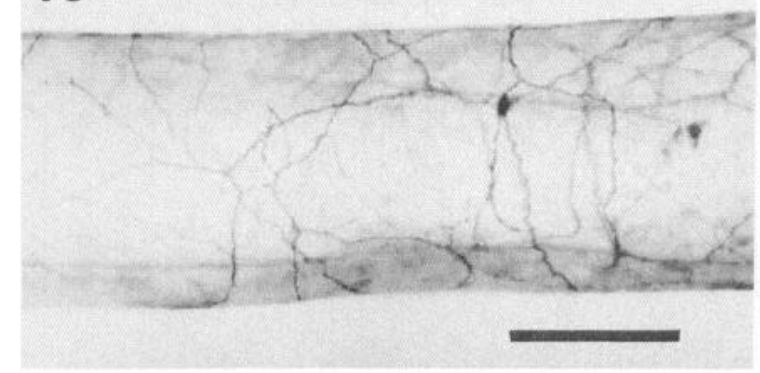


Table 3. Effects of NT3 antiserum on the percentage of NPY-ir neurons in SCG in experiment 2.

\begin{tabular}{llll} 
& \multicolumn{2}{l}{$\%$ of NPY-ir neurons $\pm \operatorname{SEM}(n)$} & \\
\cline { 2 - 3 } Treatment & NRS & NT3AS & Reduction \\
\hline Exp. 2 (P1-14) & $53.8 \pm 1.4(3)$ & $28.0 \pm 2.9(3)$ & $48.0 \%$
\end{tabular}

After an immunohistochemical procedure as described, sections were counterstained with neutral red. Total number of neurons and NPY ir neurons in four microscopic fields with $0.125 \mathrm{~mm}^{2}$ area each from different sections of each animal counted and the percentage of NPY positive neurons calculated. $* * p<0.001$

The simplest explanation for our findings is that neonatal sympathetic neurons survive as a result of the supply of both NGF and NT3. How these two factors interact is not clear. It is possible that NT3 acts indirectly via the regulation of trkA expression in the sympathetic neurons. Recently, Verdi and Anderson (1994) showed that NT3 upregulates trkA expression in sympathetic neuroblasts and differentiated neurons in culture. Thus depletion of endogenous NT3 may result in a downregulation of trkA leading to a reduced supply of NGF to the neurons. The possibility that the sympathectomy seen in earlier experiments using NGF antisera was due to an effect by contamination NT3 antibodies seems unlikely, since we have previously used a rabbit NGF antiserum for such studies (Hill et al., 1988) and now shown that this antiserum shows no significant cross-reactivity with NT3 (Zhou et al 1993; 1994).

There is evidence for distinct signaling pathways by the different trk C isoforms (Lamballe et al., 1993; Tsoulfas et al., 1993), so that a simultaneous and totally independent requirement for both factors is possible. However, scveral other possibilities deserve further investigation. Estimation of NGF levels in the rat SCG has shown that its concentration is very low at birth and rises only slowly during the first 2 postnatal weeks (Korsching and Thoenen, 1988). Even at 2 weeks of age the concentration is only about $30 \%$ of that within the adult. Thus NT3 levels within the ganglia may decline as the NGF levels increase. Loss of significant quantities of either NGF or NT3 might then be expected to result in cell death. Alternatively, NT3 may be provided from preganglionic fibers since preganglionic neurons are known to provide essential trophic support during development which cannot be explained totally by the action of ACh (for review, see Hendry, 1976; Black, 1978). A possible indirect action of NT3 antiserum via downregulation of trk A receptors has been discussed above. Finally, if heterodimers of NGF and NT3 (Junbluth et al., 1994) exist in vivo, such a molecule might be inhibited by NGF and NT3 antisera. Each of these possible mechanisms is currently under investigation.

\section{References}

Abercrombie M (1946) Estimation of nuclear population from microtome sections. Antat Rec 94:239-247.

Aguayo AJ, Peyronnard JM, Terry LC, Romine JS, Bray GM (1976) Neonatal neuronal loss in rat superior cervical ganglia: retrograde effects on developing preganglionic axons and Schwann cells. J Neurocytol 5:137-155.

Aguayo AJ, Terry LC, Bray GM (1973) Spontaneous loss of axons in sympathetic unmyelinated nerve fibers of the rat during development. Brain Res 54:360-364.

Barde Y-A, Edgar D, Thoenen H (1982) Purification of a new neurotrophic factor from mammalian brain. EMBO J 1:549-553.

Barbacid M (1993) Nerve growth factor: a tale of two receptors. Oncogene 8:2033-2042.

Barres BA, Raff MC, Gaese F, Bartke I, Dechant G, Barde Y-A (1994)
A crucial role for neurotrophin-3 in oligodendrocyte development. Nature 367:371-375.

Berkemeier LR, Winslow JW, Kaplan DR, Nikolics K, Goeddel DV, Rosenthal A (1991) Neurotrophin-5: a novel neurotrophic factor that activates trk and trkB. Neuron 7:857-866.

Birren SJ, Lo L, Anderson DJ (1993) Sympathetic neuroblasts undergo a developmental switch in trophic dependence. Development 119: $597-610$.

Black IB (1978) Regulation of autonomic development. Annu Rev Neurosci 1:183-214.

Chao MC, Bothwell MA, Ross AH, Koprowski H, Lanahan AA, Buck CR, Sehgal A (1986) Gene transfer and molecular cloning of the human NGF receptor. Science 232:518-521.

Chao MV (1992) Neurotrophin receptors: a window into neuronal differentiation. Neuron 9:583-593.

Colien S (1960) Purification of a nerve growth promoting protein from the mouse salivary gland and its neurocytotoxic antiserum. Proc Natl Acad Sci USA 46:302-311.

Cowen T (1993) Ageing in the autonomic nervous system: a result of nerve-target interactions? A review. Mech Ageing Dev 68:163-173.

Crowley C, Spencer SD, Nishimura MC, Chen KS, Pitts-Meek S, Armanini MP, Ling LH, McMahon SB, Shelton DL, Levinson AD, Phillips HS (1994) Mice lacking nerve growth factor display perinatal loss of sensory and sympathetic neurons yet develop basal forebrain cholinergic neurons. Cell 76:1001-1011.

De Champlain J, Malmfors T, Olson L, Sachs C (1970) Ontogenesis of peripheral adrenergic neurons in the rat: pre- and postnatal observations. Acta Physiol Scand 80:276-288.

Dechant G, Rodriguez-Tebar A, Kolbeck R,Barde Y-A (1993) Specific high-affinity receptors for neurotrophin-3 on sympathetic neurons. $J$ Neurosci 13:2610-2616.

DiCicco-Bloom E, Friedman WJ, Black IB (1993) NT-3 stimulates sympathetic neuroblast proliferation by promoting precursor survival. Neuron 11:1101-1111.

DiStefano PS, Friedman B, Radziejewski C, Alexander C, Boland P, Schick CM, Lindsay RM, Wiegand SJ (1992) The neurotrophins BDNF, NT-3, and NGF display distinct patterns of retrograde axonal transport in peripheral and central neurons. Neuron 8:983-993.

Dixon JE, McKinnon D (1994) Expression of the trk gene family of neurotrophin receptors in prevertebral sympathetic ganglia. Dev Brain Res 77:177-182.

Ebendal T, Oslon L, Seiger A, Hedlund K-O (1980) Nerve growth factors in the rat iris. Nature 286:25-28.

Edwall B, Gazelius B, Gazekas A, Theodorsson-Norheim E, Lundberg JM (1985) Neuropeptide Y (NPY) and sympathetic control of blood flow in oral mucosa and dental pulp in the cat. Acta Physiol Scand 125:253-264.

Ernfors P, Ibanez CF, Ebendal T, Olson L, Persson, H (1990) Molecular cloning and neurotrophic activities of a protein with structural similarities to nerve growth factor: developmental and topographical expression in the brain. Proc Natl Acad Sci USA 87:5454-5458.

Ernfors P, Lee K-F, Jaenisch R (1994a) Mice lacking brain-derived neurotrophic factor develop with sensory deficits. Nature 368:147150.

Ernfors P, Lee K-F, Kucera J, Jaenisch R (1994b) Lack of neurotrophin-3 leads to deficiencies in the peripheral nervous system and loss of limb proprioceptive afferents. Cell 77:503-512.

Farinas I, Jones KR, Bachus C, Wang X-Y, Reichardt LF (1994) Severe sensory and sympathetic deficits in mice lacking neurotrophin-3. Nature 369:658-661.

Gaese F, Kolbeck F, Barde Y-A (1994) Sensory ganglia require neurotrophin-3 early in development. Development 120:1613-1619.

Gocdert M, Otten U, Thoenen H (1978) Biochemical effects of antibodies agaist nerve growth factor on developing and differentiated sympathetic ganglia. Brain Res 148:264-268.

Götz R, Koster R, Winkler C, Raulf F, Lottspeich F, Schartl M, Thoenen H (1994) Neurotrophin-6 is a new member of the nerve growth factor family. Nature 372:266-269.

Hallböök F, Ibanez CF, Persson H (1991) Evolutionary studies of the nerve growth factor family reveal a novel member abundantly expressed in Xenopus ovary. Neuron 6:845-858.

Heym C, Liu N, Gleich A, Oberst P, Kummer W (1993) Immunohistochemical evidence for different pathways immunoreactive to substance $\mathbf{P}$ and calcitonin gene-related peptide (CGRP) in the guineapig stellate ganglion. Cell Tissue Res 272:563-574. 
Hendry IA (1976) Control in the development of the vertebrate sympathetic nervous system. In: Reviews of neuroscience, Vol 2 (Ehrenpreis S, Kopin IJ, eds), pp 149-194. New York: Raven.

Hendry IA, Campbell J (1976) Morphometric analysis of rat superior cervical ganglia after axolomy and nerve growh factor trealment. J Neurocytol 5:351-360.

Hendry IA (1977) Cell division in the developing sympathetic nervous system. J Neurocytol 6:299-309.

Hill CE, Hendry IA, Ngu MG, Van Helden DF (1985) Subpopulation of sympathetic neurones differ in their sensitivity to nerve growth factor antiserum. Dev Brain Res 23:121-130.

Hohn A, Leibrock J, Bailey K, Barde Y-A (1990) Identification and characterization of a novel member of the nerve growth factor/brain derived neurotrophic factor family. Nature 344:339-341.

Ip NY, Ibanez CF, Nye SH, McClain J, Jones PF, Gies DR, Belluscio L, Le Beau MM, Espinosa R II, Squinto SP, Persson II, Yancopoulos GD (1992) Mammalian neurotrophin-4: structure, chromosomal localization, tissue distribution, and receptor specificity. Proc Natl Acad Sci USA 89:3060-3064.

Ip NY, Stitt TN, Tapley P, Klein R, Glass DJ, Fandl J, Greene LA, Barbacid M,Yancopoulos GD (1993) Similarities and differences in the way neurotrophins interact with the Trk receptors in neuronal and nonneuronal cells. Neuron 10:137-149.

Iohnson EM Jr, Gorin PD (1980) Dorsal root ganglion neurons are destroyed by exposure in utero to maternal antibody to nerve growth factor. Science 210:916-918.

Jones KR, Farinas I, Backus C, Reichardt LF (1994) Targeted disruption of the BDNF gene perturbs brain and sensory neuron development but not motor neuron development. Cell 76:989-999.

Jungbluth S, Bailey K, Barde Y-A (1994) Purification and character-. isation of a brain-derived neurotrophic factor/neurotrophin-3 (BDNF/ NT-3) heterodimer. Eur J Biochem 221:677-685.

Kaplan DR, Martin-Zanca D, Parada LF (1991) Tyrosine phosphorylation and tyrosine kinase activity of the trk proto-oncogene product induced by NGF. Nature 350:158-160.

Klein R, Jing S, Nanduri V, O'Rourke E, Barbacid M (1991a) The trk proto-oncogene encodes a receptor for nerve growth factor. Cell 65 : 189-197.

Klein R, Lamballe F, Bryant S, Barbacid M (1992) The trkB tyrosine protein kinase is a receptor for neurotrophin-4. Neuron 8:947-956.

Klein R, Martin-Zanca D, Barbacid M, Parada LF (1990) Expression of the tyrosine kinase receptor gene trkB is confined to the murine embryonic and adult nervous system. Development 109:845-850.

Klein R, Nanduri V, Jing S, Lamballe F, Tapley P, Bryant S, CordonCardo C, Jones KR, Reichardt LF, Barbacid M (1991b) The trkB tyrosine protein kinase is a receptor for brain-derived neurotrophic factor and neurotrophin-3. Cell 66:395-403.

Klein R, Smeyne RJ, Wurst W, Long LK, Auerbach BA, Joyner AL, Barbacid M (1993) Targeted disruption of the trkB neurotrophin receptor gene results in nervous system lesions and neonatal death. Cell 75:113-122.

Klein R, Silos-Santiago I, Smeyne RJ, Lira SA, Brambilla R, Bryant S, Zhang L, Snider WD, Barbacid M (1994) Disruption of the neurotrophin-3 receptor gene trkC eliminates Ia muscle afferents and results in abnormal movements. Nature 368:249-251.

Korsching S, Thoenen H (1988) Developmental changes of nerve growth factor levels in sympathetic ganglia and their target organs. Dev Biol 126:40-46.

Kummer W, Heym C (1991) Different types of calcitonin gene-related peptide-immunoreactive neurons in the guinea-pig stellate ganglion as revealed by triple-labelling immunofluorescence. Neurosci Lett 128:187-190.

Lamballe F, Klein R, Barbacid M (1991) trkC, a new member of the trk family of tyrosine protein kinases, is a receptor for neurotrophin3. Cell 66:967-979.

Lamballe F, Smeyne RJ, Barbacid M (1994) Developmental expression of trkC, the neurotrophin- 3 receptor, in the mammalian nervous system. J Neurosci 14:14-28.

Lamballe F, Tapley P, Barbacid M (1993) trkC encodes multiple neurotrophin-3 receptors with distinct biological properties and substrate specificities. EMBO J 12:3083-3094.

Lee K-F, Davies AM, Jaenisch R (1994) p75-deficient embryonic dorsal root sensory and neonatal sympathetic neurons display a decreased sensitivity to NGF. Development 120:1027-1033.

Leibrock J, Lottspeich F, Hohn A, Hofer M, Hengerer B, Masiakowski
P, Thoenen H, Barde Y-A (1989) Molecular cloning and expression of brain derived neurotrophic factor. Nature 341:149-152.

Levi-Montalcini R, Booker B (1960) Destruction of the sympathetic ganglia in mammals by an antiserum to nerve growth protein. Zoology $46: 384-391$.

Majewski M, Heym C (1992) Immunohistochemical localization of calcitonin gene-related peptide and cotransmitters in a subpopulation of post-ganglionic neurons in the porcine inferior mesenteric ganglion. Acta Histochem 92:138-146.

Maisonpierre PC, Belluscio L, Squinto S, Ip NY, Furth ME, Lindsay RM, Yancopoulos GD (1990) Neurotrophin-3: a neurotrophic factor related to NGF and BDNF. Science 247:1446-1451.

Martin-Zanca D, Barbacid M, Parada LF (1990) Expression of the trk proto-oncogene is restricted to the sensory cranial and spinal ganglia of neural crest origin in mouse development. Genes Dev 4:683-694.

Martin-Zanca D, Oskam R, Mitra G, Copeland T, Barbacid M (1989) Molecular and biochemical characterization of the human trk protooncogene. Mol Cell Biol 9:24-33.

Miller FD, Mathew TC, Toma JG (1991) Regulation of nerve growth factor receptor gene expression by nerve growth factor in the developing peripheral nervous system. J Cell Biol 112:303-312.

Murphy RA, Acheson A, Hodges R, Haskins J, Richards C, Reklow E, Chlumecky V, Barker PA, Alderson RF, Lindsay RM (1993) Immunological relationships of NGF, BDNF, and NT-3: recognition and functional inhibition by antibodies to NGF. J Neurosci 13:2853-2862.

Negro A, Corsa V, Skaper SD, Callegaro L (1993) Nerve growth factor antibodies recognize neurotrophin-3. Ncurochem Res 18:705-709.

Oswald RJ, Byers MR (1993) The injury response of pulpal NPY-IR sympathetic fibers differs from that of sensory afferent fibers. Neurosci Lett 164:190-194.

Pow DV, Crook, DK (1993) Extremely high titre polyclonal antisera against small neurotransmitter molecules: rapid production, characterisation and use in light- and electron-microscopic immunocytochemistry. J Neurosci Methods 48:51-63.

Raffioni S, Bradshaw RA. Buxser SE (1993) The receptors for nerve growth factor and other neurotrophins. Annu Rev Biochem 62:823850.

Rosenthal A, Goeddel DV, Nguyen T, Lewis M, Shih A, Laramee GR, Nikolics K, Winslow JW (1990) Primary structure and biological activity of a novel human neurotrophic factor. Neuron 4:767-773.

Rubin E (1985a) Development of the rat superior cervical ganglion: initial stages of synapse formation. J Neurosci 5:697-704.

Rubin E (1985b) Development of the rat superior cervical ganglion: ingrowth of preganglionic axons. J Neurosci 5:685-696.

Rubin E (1985c) Development of the rat superior cervical ganglion: ganglion cell maturation. J Neurosci 5:673-684.

Ruit KG, Snider WD (1991) Administration or deprivation of nerve growth factor during development permanently alters neuronal geometry. J Comp Neurol 314:10.

Ruit KG, Elliott JL, Osborne PA, Yan Q, Snider WD (1992) Selective dependence of mammalian dorsal root ganglion neurons on nerve growth factor during embryonic development. Neuron 8:573-587.

Scarisbrick IA, Jones EG, Isackson PJ (1993) Coexpression of mRNAs for NGF, BDNF, and NT-3 in the cardiovascular system of the preand postnatal rat. J Neurosci 13:875-893.

Schecterson LC, Bothwell M (1992) Novel roles for neurotrophins are suggested by BDNF and NT-3 mRNA expression in developing neurons. Neuron 9:449-463.

Schmitt M, Kummer W, Heym C (1988) Calcitonin gene-related peptide (CGRP)-immunoreactive neurons in the human cervico-thoracic paravertebral ganglia. J Chem Neuroanat 1:287-292.

Smeyne RJ, Klein R, Schnapp A, Long LK, Bryant S, Lewin A, Lira $S \Lambda$, Barbacid M (1994) Severe sensory and sympathetic neuropathies in mice carrying a disrupted Trk/NGF receptor gene. Nature 368:246-249.

Soppet D, Escandon E, Maragos J, Middlemas DS, Reid SW, Blair J, Burton LE, Stanton BR, Kaplan DR, Hunter T, Nikolics K, Parada LF (1991) The neurotrophic factors brain-derived neurotrophic factor and neurotrophin- 3 are ligands for the trkB tyrosine kinase receptor. Cell 65:895-903.

Squinto SP, Stitt TN, Aldrich TH, Davis S, Bianco SM, Radziejewski C, Glass DJ, Masiakowski P, Furth ME, Valenzuela DM, DiStefano PS, Yancopoulos GD (1991) trkB encodes a functional receptor for brain-derived neurotrophic factor and neurotrophin-3 but not nerve growth factor. Cell 65:885-893. 
Tessarollo L, Tsoulfas P, Martin-Zanca D, Gilbert DJ, Jenkins NA, Copeland NG, Parada LF (1993) trkC, a receptor for neurotrophin-3, is widely expressed in the developing nervous system and in nonneuronal tissues. Development 118:463-475.

Tsoulfas P, Soppet D, Escandon E, Tessarollo L, Mendoza-Ramircz J-L, Rosenthal A, Nikolics K, Parada LF (1993) The rat trkC locus encodes multiple neurogenic receptors that exhibit differential response to neurotrophin-3 in PC12 cells. Neuron 10:975-990.

Verdi JM, Anderson DJ (1994) Neurotrophins regulate sequential changes in neurotrophin receptor expression by sympathetic neuroblasts. Neuron 13:1359-1372.

Wright LL, Cunningham TJ, Smolen AJ (1983) Developmental neurons death in the rat superior cervical sympathetic ganglion: cell counts and ultrastructure. J Neurocytol 12:727-738.

Yan Q, Johnson EM Jr (1988) An immunohistochemical study of the nerve growth factor receptor in developing rats. J Neurosci 8:3481-3.
Yan Q, Johnson EM Jr (1989) Immunohistochemical localization and biochemical characterization of nerve growth factor receptor in adult rat brain. J Comp Neurol 290:585-598.

Zhou X-F, Williams R, Vahaviolos J, Zettler C, Rush RA (1993a) Ovalbumin-like immunoreactivity detected in chicken sensory neurons by antibodies to aldehyde-treated ovalbumin. Histochem $\mathrm{J}$ 25:865-871.

Zhou X-F, Parada LF, Soppet D, Rush RA (1993b) Localization of trkB tyrosine kinase immunoreactivity in the rat central nervous system. Brain Res 622:63-70.

Zhou X-F, Zettler C, Rush RA (1994a) An improved procedure for the immunohistochmcal localization of nerve growth factor-like immunoreactivity. J Neurosci Methods 54:95-102.

Zhou X-F, Williams R, Zecevic M, Rush RA (1994b) Peripheral projections of a subpopulation of dorsal root ganglion neurons defined by ovalbumin immunoreactivity. J Neurocytol 23:271-277. 